\title{
The Relation between Individual Characteristics and Job Stress in PT. PAL Indonesia
}

\section{Hubungan antara Karakteristik Individu dengan Stres Kerja di PT. PAL Indonesia}

\author{
Siti Hardiyanti Putri Pratiwi, Tri Martiana, Shintia Yunita Arini \\ Department of Occupational Safety and Health, Faculty of Public Health, Universitas Airlangga \\ Campus C Mulyorejo, Surabaya, East Java, 60115 Indonesia
}

\begin{abstract}
Introduction: Quality Assurance and Quality Control Division workers are challenged by various mental and physical pressures that might trigger job stress. Many factors contribute to job stress, one of them is the individual factor. This study's purpose was to examine and analyze whether or not there was a relation between the individual characteristic factors and job stress at PT. PAL Indonesia (Quality Assurance and Quality Control Division). Methods: This research was a cross-sectional study. This research had a population of 49 people. The sample was counted using a simple random sampling method and 44 people were obtained as samples. This study's independent variables were individual characteristics (working period, age, sex, and marital status) and job stress as the dependent variable. Data collection methods for this study were interviews with a questionnaire guide. The data analysis technique used was Fisher's Exact. Results: The result of Fisher Exact statistical test showed that there was not any relation between working period and job stress $(p=0.170)$, age and job stress $(p=0.456)$, gender and job stress $(p=0.290)$, marital status and job stress $(p=$ 1,000). Conclusion: It can be concluded that individual characteristics has no significant relationship with job stress on employees of the Quality Assurance and Quality Control division of PT. PAL Indonesia (Persero).
\end{abstract}

Keywords: individual characteristics, job stress, quality assurance and quality control division

ABSTRAK

Pendahuluan: Pekerja Divisi Quality Assurance and Quality Control dalam menjalankan pekerjaannya menghadapi berbagai tekanan secara fisik maupun mental yang dapat mengakibatkan stres kerja. Terdapat banyak faktor yang menjadi penyebab timbulnya stress kerja, salah satunya adalah faktor individu. Tujuan dari penelitian ini adalah menganalisis hubungan antara faktor karakteristik individu dengan stress kerja di PT. PAL Indonesia (Divisi Quality Assurance and Quality Control). Metode: Penelitian ini merupakan penelitian cross sectional. Populasi dalam penelitian ini berjumlah 49 orang. Jumlah sampel dihitung dengan teknik simple random sampling, sampel penelitian ini sebanyak 44 orang. Variabel independent dalam penelitian ini adalah karakteristik individu (masa kerja, usia, jenis kelamin, dan status pernikahan) dan Variabel dependent adalah stress kerja. Metode yang digunakan dalam pengumpulan data adalah wawancara dengan panduan kuesioner. Teknik analisis data dalam penelitian ini adalah Fisher's Exact. Hasil: Hasil uji statistik Fisher's Exact menunjukkan bahwa tidak ada hubungan antara masa kerja dengan stress kerja $(p=0,170)$, usia dengan stres kerja ( $p=$ 0,456), jenis kelamin dengan stress kerja (0,290), status pernikahan dengan stress kerja ( $p=1,000)$. Simpulan: Dapat disimpulkan bahwa Karakteristik individu tidak memiliki hubungan yang signifikan dengan stres kerja pada pekerja divisi Quality Assurance and Quality Control PT. PAL Indonesia (Persero).

Kata kunci: divisi quality assurance and quality control, karakteristik individu, stress kerja

Corresponding Author:

Siti Hardiyanti Putri Pratiwi

Email: siti.hardiyanti.putri-2016@fkm.unair.ac.id

Phone: +628962749958

\section{INTRODUCTION}

Job stress is one of the many psychological problem aspects in the Occupational Health that becomes the main focus for the labors. Job stress is a form of mental pressure that the employees/workers need to deal with in their daily job (Mangkunegara, 2013). Job stress, according to the opinion of Wijono (2010), is a condition based on the appreciation of an

(C2020 IJOSH All right reserved. Open access under CC BY NC-SA license doi: 10.20473/ijosh.v9i3.2020.248-257 Received July 06, 2020, received in revised form August 01, 2020, Accepted October 31, 2020, Published: November 2020 
individual's subjective perspective that can happen as an interaction between individuals and their work environment that may cause psychological, physiological, and individual attitude pressure. Job stress may have negative effects on both the individual itself and the company. The effect of job stress on an individual could be in the form of emotional reaction, mental or habit change, and physiological change. Meanwhile, its effect on the company could be in the form of a decreased attendance rate, low work-rate performance, and the increased worker turnovers that may cause working time losses thus crippling the organization (Tarwaka, 2015).

Job stress can also cause a sizeable profit loss. Based on The American Institute of Stress (2013) data, the American industry experienced a loss of over 300 billion US dollars per year because of accidents, work-absence, turnover, productivity decline, and insurance compensation due to the job stress affecting their workers. Besides that, the case of job-caused stress, dismay, or depression in England was recorded to be at 526.000 in 2016 with 1.610 cases per 100.000 workers as the prevalence rate. The amount of missing workdays caused by this condition was estimated to be at 12.5 million days, averaged at 23.8 days missing per case (The UK National Job stress, 2017).

While job stress level or rates has not been specifically researched before in Indonesia, some studies about it showed that Indonesia had a pretty high rate of job stress. According to the research performed by Widyastuti (2018) directed on the box truck construction workshop worker, showing that of 15 workers, 9 of those $(60 \%)$ were experiencing an average job stress level, meanwhile, only 1 person $(6.67 \%)$ had a job stress in a low level, and job stress in a high level was experienced by the other 5 people $(33.33 \%)$. Based on the research performed by Manabung, et al. (2018) on the labor of PT. Pertamina TBBM Bitung, the average job stress level was shown to have affected 38 out of 62 respondents $(61.3 \%), 17$ respondents $(27.4 \%)$ with a high job stress level, and the other $7(11.3 \%)$ had a low job stress level.

Tarwaka (2015) in his research stated that several factors that may contribute to job stress were the job's intrinsic factor, the individual role in a working organization, work relationship factor, career expansion factor, organizational structure factor, work environment factor, and other factors that came from the outside of the job. The other factors are the individual characteristics factors such as work period, age, gender, and marital status, which is categorized as an internal factor (Munandar, 2012). This is in line with research by Koesindratmono (2011) on PT. Perkebunan Nusantara X (Persero) which stated that a relation between work periods and job stress occurrence did exist, with a p-value of $0.012<0.05$. This statement is further reinforced by the opinion of Munandar (2012), who said that in general, workers who have worked longer in a company will be more comfortable with their work. However, when the work is done monotonously, it will cause burnout, so workers become stressed.

In the study done by Ansori and Martiana (2017) on dental nurses, a strong and direct connection between age and job stress did exist. This study also referred to that 22 dental nurse respondents in this study showed that women were the respondents who experienced the most job stress, which was why $14(73.3 \%)$ people were in the moderate stress category. The result of the statistical test was known to have an r-value of 0.557 , which means that the gender variables and job stress relation on dental nurses were strong and unidirectional. According to research done by Utami (2010) on nurses at Pelni Petamburan Hospital resulted that marital status had a connection with job stress with a P-Value of 0.031 . For an individual, marital status is considered to be an influential factor because if an individual has been married then the responsibilities and obligations are directed not only to himself but also to his family. This status creates additional burden for an individual during work, thus triggers the job stress.

The Quality Assurance and Quality Control Division is one of the most important roles in elevating the product quality of the company. This division is being tasked to control the incompatibility of the designs or product results, construction material for new ships or non-ship-related products, and also to evaluate all of the previously mentioned products or designs. This division is also responsible for planning the strategy and the quality assurance system managements starting from the materials identification, production process, all the way to the inspection phase and final test based on the established terms and conditions.

Becoming a part of the Quality Assurance and Quality Control Division creates a heavy responsibility because this division has to be responsible for other's work and their own. The 
number of responsibilities carried out by the Quality Assurance and Quality Control Division workers will lead to a stress-prone assignment. 35 (71.4\%) workers in the Quality Assurance and Quality Control Division of PT. PAL Indonesia (Persero) mostly has a long working period ( $>3$ years). Based on interviews with HSE officers at PT PAL Indonesia (Persero), the work period is categorized as one of many factors contributing to the occurrence of job stress. This is because workers with long working periods will tend to get bored with monotonous workflow and routine. Furthermore, workers with a long work period felt that retirement is always in front of their eyes, making workers felt anxious and afraid of losing their jobs.

According to the result obtained from an interview section with the secretary of the division, most of the workers were in the middle age category, which was between 35-50 years old. According to Anoraga (2014), the older someone gets, the level of accuracy and speed will decline, the more difficult to adapt, and gets tired easily. This means that aging for an individual can lead to job stress. Based on field observations, most of the employees in the Quality Assurance and Quality Control Division were males $(91.8 \%)$. This is because employees in the Quality Assurance and Quality Control Division have strenuous physical activities such as getting on and off ship engines, moving from one ship to another, etc. It indicates that this field of work is considered unsuitable for female workers.

Based on interviews with the secretaries of the division, the majority of workers are married. A married worker does not only think about the needs of his own life but must also think about the family's well-being as well. This factor is what may trigger job stress. Based on this background, this study's objective was established, which was to examine and analyze the relationship between individual characteristics which includes work period, age, gender, and marital status factors and job stress in PT. PAL Indonesia (Quality Assurance and Quality Control Division).

\section{METHODS}

This research was conducted by using an analytical observation method. The design of the study was cross-sectional. The place for this research was at the location of PT. PAL Indonesia (Persero). This research was carried out in February of 2020. The population of this research was all of the labors in the Quality Assurance and Quality
Control Division of PT. PAL Indonesia (Persero) that amounts to 49 people. The obtained samples were calculated by a simple random sampling method and 44 workers were obtained as the samples.

The independent variables used for this research were the working period, age, gender, and marital status. The dependent variable studied was job stress. The data gathering method used in this research was the individual characteristic questionnaire (working period, age, gender, and marital status), while the job stress questionnaire used was done by using the scoring method modified from the HSE Indicator Tool questionnaire (2003) consisting of 25 questions.

The statistical analysis conducted in this study was the Chi-Square method, with a significance level $(\alpha)$ of $5 \%$ and a confidence level (CI) of $95 \%$. The requirement for this Chi-Square test was met if there were no cells with an expectation value of less than 5 and do not have a percentage level of $>20 \%$. However, if these requirements cannot be achieved, then an alternative called Fisher Exact Test. Both variables were concluded to have a relationship if the level of significance is $\leq 0.05$, which mean the value of Ho will be rejected and the value of Ha will be accepted. The ethical certificate of this research is received from the ethics committee of Public Health Faculty Universitas Airlangga No.10/EA/ $\mathrm{KEPK} / 2020$.

\section{RESULT}

In this research, the data were obtained through an individual characteristic questionnaire. The table of the distribution of research results on employees of the Quality Assurance and Quality Control division of PT. PAL Indonesia (Persero) with the explanation is presented as follows.

\section{Working Period}

In table 1 , it is shown that the majority of the workers in the Quality Assurance and Quality Control Division of PT. PAL Indonesia (Persero) who had an old working period ( $>3$ years) were 31 workers with a percentage of $70.5 \%$. The workers that had a new working period ( $\leq 3$ years) were 13 people with a percentage of $29.5 \%$.

Age

Table 2 indicates that most of the workers in the Quality Assurance and Quality Control Division of PT. PAL Indonesia (Persero) were in the category of Average Adults (30-58 years) totaling of 33 people 
Table 1. Distribution of the Working Period for the Workers in the Quality Assurance and Quality Control Division of PT. PAL Indonesia (Persero) in February 2020

\begin{tabular}{ccc}
\hline \multirow{2}{*}{$\begin{array}{c}\text { Working Period } \\
\text { (Years) }\end{array}$} & \multicolumn{2}{c}{ Total Respondents } \\
\cline { 2 - 3 } & Frequency (n) & Percentage (\%) \\
\hline $\begin{array}{c}\text { New Working } \\
\text { Period ( } \leq 3 \text { years) } \\
\text { Old Working } \\
\text { Period ( }>3 \text { years) }\end{array}$ & 13 & 29.5 \\
\hline Total & 31 & 70.5 \\
\hline
\end{tabular}

Table 2. Distribution of the Age Factor for the Workers in the Quality Assurance and Quality Control Division of PT. PAL Indonesia (Persero) in February 2020

\begin{tabular}{ccc}
\hline \multirow{2}{*}{ Age (years) } & \multicolumn{2}{c}{ Total Respondents } \\
\cline { 2 - 3 } & Frequency (n) & Percentage (\%) \\
\hline $\begin{array}{c}\text { Young Adult (21-29 } \\
\text { years old) } \\
\begin{array}{c}\text { Average Adult (30- } \\
58 \text { years old) }\end{array}\end{array}$ & 11 & 25.0 \\
\hline Total & 33 & 75.0 \\
\hline
\end{tabular}

with a percentage of $44.9 \%$, and in the category of Young Adult (21-29 years old) were 33 workers with a percentage $(42.9 \%)$.

\section{Gender}

Based on Table 3, most of the respondent distribution for the workers in the Quality Assurance and Quality Control Division based on the gender was male by 40 workers and a percentage of $90.9 \%$. Meanwhile, the female worker only amounts to 4 people with a percentage of $9.1 \%$.

\section{Marital Status}

Based on Table 4, the majority of the workers in the Quality Assurance and Quality Control Division of PT. PAL Indonesia (Persero) has been married by 34 workers with a percentage of $77.3 \%$. Meanwhile, 10 workers $(22.7 \%)$ were not married.

\section{Job Stress}

Table 5 indicates that most of the workers in the Quality Assurance and Quality Control Division of PT. PAL Indonesia (Persero) had a high job stress level by 30 people (53.1\%), while 14 workers $(28.6 \%)$ had low job stress level.
Table 3. Distribution of the Gender Factor for the Workers in the Quality Assurance and Quality Control Division of PT. PAL Indonesia (Persero) in February 2020

\begin{tabular}{ccc}
\hline \multirow{2}{*}{ Gender } & \multicolumn{2}{c}{ Total Respondents } \\
\cline { 2 - 3 } & Frequency (n) & Percentage (\%) \\
\hline Male & 40 & 90.9 \\
Female & 4 & 9.1 \\
\hline Total & 44 & 100.0 \\
\hline
\end{tabular}

Table 4. Distribution of the Marital Status for the Workers in the Quality Assurance and Quality Control Division of PT. PAL Indonesia (Persero) in February 2020

\begin{tabular}{ccc}
\hline \multirow{2}{*}{ Marital Status } & \multicolumn{2}{c}{ Total Respondents } \\
\cline { 2 - 3 } & Frequency (n) & Percentage (\%) \\
\hline Non-married & 10 & 22.7 \\
Married & 34 & 77.3 \\
\hline Total & 44 & 100.0 \\
\hline
\end{tabular}

Table 5. Distribution of the Job Stress Level for the Workers in the Quality Assurance and Quality Control Division of PT. PAL Indonesia (Persero) in February 2020

\begin{tabular}{ccc}
\hline \multirow{2}{*}{ Job Stress } & \multicolumn{2}{c}{ Total Respondents } \\
\cline { 2 - 3 } & Frequency (n) & Percentage (\%) \\
\hline Low Job Stress & 14 & 31.8 \\
High Job Stress & 30 & 68.2 \\
\hline Total & 44 & 100.0 \\
\hline
\end{tabular}

\section{Work Period and Job Stress}

The relation analysis between the working period and job stress was conducted by using Fisher's Exact Test. The relation between the working period and job stress is presented in table 6.

Table 6 shows that out of 13 workers with a new working period ( $\leq 3$ years) 11 workers $(84.6 \%)$ in this category were experiencing high job stress. Besides that, there were 31 workers with the old working period ( $>3$ years) and 19 workers $(61.3 \%)$ in this category were shown to have a high job stress level.

The statistical test results showed that the chisquare test score was unusable due to the table that has an expected count value of $<5$ and above $20 \%$, therefore the test used was Fisher's exact test, 
resulting the $p$-value of 0.170 obtained. When this value was compared with the value of $\alpha(0.05)$, the value of $p(0.170)$ was greater than $\alpha$, meaning that a work period had no connection with the job stress in the workers of the Quality Assurance and Quality Control of PT. PAL Indonesia (Persero).

\section{Age and Job Stress}

The relation between age and job stress in the Quality Assurance and Quality Control Division of PT. PAL Indonesia (Persero) was conducted by using the fisher's exact test. Presented in Table 7 below is the relation between the age factor and job stress.

Table 7 shows that on 11 workers in the age category of Young Adult (21-29 years old), about 9 workers $(81.8 \%)$ in this category had a high job

Table 6. The Cross-tabulation Between Working Period and Job Stress for the Workers in the Quality Assurance and Quality Control Division of PT. PAL Indonesia (Persero) in February 2020

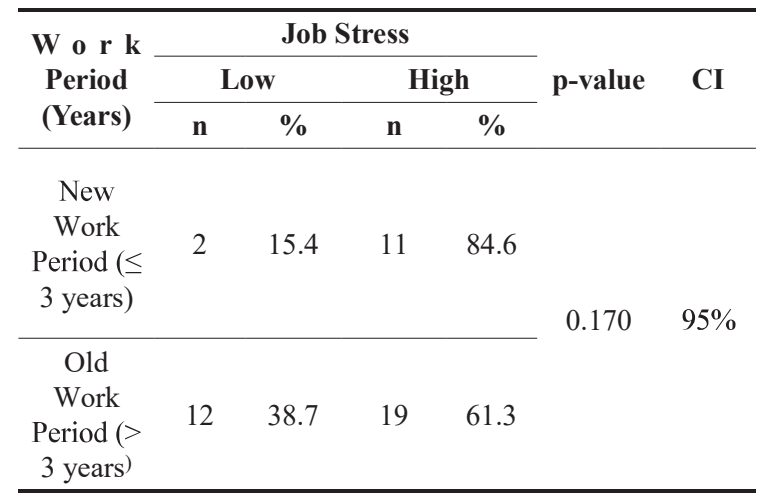

Table 7. The Cross-tabulation Between Age and Job Stress for Labors in the Quality Assurance and Quality Control Division of PT. PAL Indonesia (Persero) in February 2020

\begin{tabular}{|c|c|c|c|c|c|c|}
\hline \multirow{3}{*}{$\begin{array}{c}\text { Wo r k } \\
\text { Period } \\
\text { (Years) }\end{array}$} & \multicolumn{4}{|c|}{ Job Stress } & \multirow{3}{*}{ p-value } & \multirow{3}{*}{ CI } \\
\hline & \multicolumn{2}{|c|}{ Low } & \multicolumn{2}{|c|}{ High } & & \\
\hline & $\mathbf{n}$ & $\%$ & $\mathbf{n}$ & $\%$ & & \\
\hline $\begin{array}{l}\text { Young } \\
\text { Adult } \\
(21-29 \\
\text { years } \\
\text { old })\end{array}$ & 2 & 18.2 & 9 & 81.8 & \multirow{2}{*}{0.456} & \multirow{2}{*}{$95 \%$} \\
\hline $\begin{array}{c}\text { Average } \\
\text { Adult } \\
(30-58 \\
\text { years } \\
\text { old) }\end{array}$ & 12 & 36.4 & 21 & 63.6 & & \\
\hline
\end{tabular}

stress level. For 21 workers at the age category between 36-50 years of age, there were 9 workers $(42.9 \%)$ in this category that were experiencing an average level of job stress. Also, there were 6 workers in the category of Average Adult (30-58 years old) who had a high job stress level.

Judging by the results of Fisher's exact test, the $\mathrm{p}$-value of 0.456 was obtained. This P-value was greater than the value of $\alpha(0.05)$, this shows that age factor and job stress in the Quality Assurance and Quality Control Division was not related.

\section{Gender and Job Stress}

The relation analysis between gender and job stress in the Quality Assurance and Quality Control Division of PT. PAL Indonesia (Persero) was conducted by a Fisher's Exact Test and the result was presented in table 8 .

Table 8 shows that among 40 male workers, there were 26 workers $(65.0 \%)$ in this category that had job stress in the high level. Additionally, 4 female workers $(100.0 \%)$ in this category were also affected by a high job stress level.

Based on the relation analysis statistics results conducted by using Fisher's Exact Test, the p-value was shown to be at 0.290, which means that the connection between gender and job stress did not

Table 8. The Cross-tabulation Between Gender and Job Stress for the Workers in the Quality Assurance and Quality Control Division of PT. PAL Indonesia (Persero) in February 2020

\begin{tabular}{|c|c|c|c|c|c|c|}
\hline \multirow{3}{*}{ Gender } & \multicolumn{4}{|c|}{ Job Stress } & \multirow{3}{*}{ p-value } & \multirow{3}{*}{ CI } \\
\hline & \multicolumn{2}{|c|}{ Low } & \multicolumn{2}{|c|}{ High } & & \\
\hline & $\mathrm{n}$ & $\%$ & $\mathrm{n}$ & $\%$ & & \\
\hline Male & 14 & 35. & 26 & 65.0 & \multirow{2}{*}{0.290} & \multirow{2}{*}{$95 \%$} \\
\hline Female & 0 & 0.0 & 4 & 100.0 & & \\
\hline
\end{tabular}

Table 9. The Cross-tabulation Between Marital Status and Job Stress for the Labors in the Quality Assurance and Quality Control Division of PT. PAL Indonesia (Persero) in February 202

\begin{tabular}{ccccccc}
\hline \multirow{2}{*}{$\begin{array}{c}\text { Marital } \\
\text { Status }\end{array}$} & \multicolumn{4}{c}{ Low Stress } & & \\
\cline { 2 - 5 } & $\mathbf{n}$ & $\mathbf{\%}$ & $\mathbf{n}$ & $\mathbf{\%}$ & & \\
\hline $\begin{array}{c}\text { Non- } \\
\text { married }\end{array}$ & 3 & 30.0 & 7 & 70.0 & & \\
Married & 11 & 32.4 & 23 & 67.6 & & \\
\hline
\end{tabular}


exist. This result happened because the p-value $(0.290)$ is bigger than the $\alpha(0.05)$ value.

\section{Marital Status and Job Stress}

The relation analysis between marital status and job stress in the Quality Assurance and Quality Control Division of PT. PAL Indonesia (persero) was conducted by using fisher's exact test as shown in the Table 9.

Table 9 shows that among 34 workers with married status, about 23 workers $(67.6 \%)$ in this category was experiencing a high job stress level. In addition, among the 10 non-married workers, 7 workers $(70.0 \%)$ in this category had a high job stress level.

Judging by the results of relation analysis statistics conducted using Fisher's Exact Test, the $\mathrm{p}$-value shows a value of 1.000 . This result means that the connection between gender and job stress did not exist because of the p-value (1.000) $>\alpha$ (0.05) value.

\section{DISCUSSION}

\section{Working Period}

According to the opinion of Koesindratmono (2011), working period is the length of how long an individual works in an agency, office, etc. Based on this study's result, the majority of the employees who work in the Quality Assurance and Quality Control Division of PT. PAL Indonesia (Persero) has worked more than 3 years while the shortest working period recorded was 2 months and the longest was at 31 years.

\section{Age}

Based on the research, the Quality Assurance and Quality Control Division of PT. PAL Indonesia (Persero) workers were at the Average Adult (3058 years old) category and had a high-stress level. This result was also stated by Anoraga (2014) in his research, which stated that when an individual ages, the accuracy and the speed will decline and resulting in harder adaptation during work and will be easily fatigued. This would make the older worker easier to experience job stress. So does with the opinion of Munandar (2012) which stated that physiological decline will occur the older the worker is, this would result in the visual, hearing, memory, and intelligence decline. This means that the older the worker is, the easier job stress will occur.

\section{Gender}

According to Bagus (2014), a Gender is a different form, nature, and biological function of men and women, that determine the difference in their role in managing lineage changes. In the category of gender, the research shows that the majority of the worker was categorized as a male. The number of male workers in the company was caused by the fact that most of the assignments in the Quality Assurance and Quality Control Division are classified as field assignments, meaning that male is most suited due to the required use of muscular and physical attributes for executing the job. Other than that, the Quality Assurance and Quality Control Division need engineering-trained labor, such as naval engineering, electrical engineering, welding engineering, and others that are less popular and less demanded by female academics.

\section{Marital Status}

Marital status is a bond that explains the relationship between a man and a woman, information on the worker's marital status is shown on the identity card (KTP). According to Tarwaka (2015), a married person generally has a lower stress level than someone who is not married. This can happen if workers receive support from their partners in their careers, so the job stress they experience will tend to decrease. This influence is positive if the marriage goes well. However, not all married individuals will experience stress while doing work. This depends on the individual's ability to solve problems that exist in his/her family so that they do not interfere his work (Sulistyana, 2018).

\section{Job Stress}

Job stress is an emotional and physical response that is disturbing or detrimental in nature which occurs if the demands of a career do not match with the performance, capabilities, desires of the worker (Tarwaka, 2015). To be able to know exactly what factors can cause stress is very difficult because it depends on a person's character and personality. A situation that can cause stress to someone, will not necessarily cause the same thing to others. One of the causes of Job stress according to Tarwaka, (2015) is individual characteristics such as years of service, age, gender and marital status. These individual 
characteristic factors can affect a person's work capacity. If the task demands and work capacity are balanced, optimal productivity will be created, so that workers will avoid Job stress.

\section{Working Period and Job Stress}

Based on the statistical analysis, the P-value $(0.170)$ was shown to have a bigger value compared to the value of $\alpha(0.05)$, meaning that the relation between the working period and job stress in the Quality Assurance and Quality Control Division of PT. PAL Indonesia (Persero) does not exist. This is because no difference found in job stress's level that were experienced by the new employees and the old employees. Additionally, the majority of the workers have been working for more than 3 years, meaning they have enough experience to resolve surfacing problems and avoiding the occurrence of job stress. From this analysis, it can be deduced that the working period was not a contributing factor that could trigger the occurrence of job stress in the Quality Assurance and Quality Control Division of PT. PAL Indonesia (Persero).

This result was related to the research conducted by Nadialis (2014) about the relationship between age, working period, and working burden with the job stress, which showed that the connection between working period and job stress was not significant. These result was in accordance with the research that was conducted by Ulum, et al. (2018) for bus rapid transit (BRT) corridor II Semarang City drivers, which shows a work period has no relationship with job stress. An individual with a longer working period is often found to be more resilient against pressures that came from a job compared to those with shorter working periods. A long working period is highly connected with the level of experience and understanding of the job itself. The experience and understanding were believed to help handling occurring problems thus avoiding the stress occurrence (Zulkifli, Shinta Tri $\mathrm{R}, 2019$ ).

The working period it is an element/factor that can increase the level of productivity, this is due to the quality of work that is attainable because of the longer working period. In addition, a longer working period will give more work experience, knowledge, and skills for a worker. Therefore, workers with a longer working period will less likely to experience job stress (Hermanto, 2012).

To that point, the same result can also be associated with the research performed by Maydinar, et al. (2020) on the Nurses of RSUD Dr, M. Yunus Operating Room, which shows that there was not any significant relation between working period and job stress. This has happened because nurses with longer and shorter working periods already have a base certificate for their job, meaning that the skills they obtained during training help in maintaining their job stress level. Other than that, workers with longer working periods have enough skills and experience to tackle the problems that occur in their workplace. This will make the worker with a longer working period more unlikely to experience job stress as a result.

The study performed by Anggraeni, et al. (2017) also resulted correspondingly, that relation between the working period and job stress for the sandblasting workers did not exist. The longer an individual works, the easier the work assigned to that individual will be and the more adaptive that individual will be as well. Meaning that worker with a longer working period will be able to avoid job stress.

\section{Age and Job Stress}

Fisher's exact test resulted a P-value of 0.456 which has a bigger value compared to the value of $\alpha$ $(0.05)$, meaning that the relation between age factor and job stress was not significant. Based on the study conducted towards the workers on the Young Adult (in the range of age of 21-29 years old) and Average Adult (in the range of age of 30-58 years old) categories, it was shown to have a high-stress level. This can be concluded that age was not a factor that triggers the occurrence of job stress on the workers of the Quality Assurance and Quality Control Division.

The result of this study is also the same as Nadialis' (2014), in which it shows that there was not any significant relation between the age factor and job stress. This happens because not all of the workers from the youngest ( 24 years old) to the oldest (56 years old) experiencing job stress. Furthermore, these results are also similar to Hartono and Siswanto (2017) research on Inpatient Nurses at the Jakarta Haji Hospital in 2017, showing that age and job stress had no relationship that was statistically significant.

A similar result is also conveyed in the research performed by Prabowo (2010) which showed that there was no significant result between the age of the workers and the job stress occurrence. This result happened because the company has differentiated 
the job given to the workers based on the age and that the company assumes that aging workers will have more experience and better adaptation ability compared to the younger workers.

The result of this research is also in conjunction with the study performed by Anggraeni, et al. (2017) on sandblasting workers, which showed that the relation between age and job stress was not significant. This happened because both older and younger workers have similar job stress. Therefore, the age variable is not affiliated with the job stress variable.

\section{Gender and Job stress}

The statistical analysis resulted in the P-value of 0.290 , which was bigger compared to the value of $\alpha(0.05)$. It shows that gender had no significant relationship with job stress factors on the workers. This result was in accordance with the research conducted by Nurini, et al. (2017) on the employees of PT. PLN (Persero) TJBT APP Cirebon which stated that not significant relationship between gender and job stress.

Study performed by Lady, et al. (2017) on the employees of the Cilegon City BPBD showed that gender factor has no relationship with job stress. However, the previously mentioned study is the opposite of the study that was conducted by Febriandini, et al. (2016) which stated that gender had a significant relationship with job stress.

This research showed that female had a higher chance to experience job stress compared to male. This result is similar to the opinion of Suma'mur (2014) stating that males and females have different physical configurations (muscles). Female is likely to get fatigued, thus resulting in a female to be experiencing job stress easier. The same opinion was also stated by Rusmania (2017) which stated that higher stress level was more commonly found in female. This happens because the female is affected by anxiety, guilty thoughts, sleeping disorder, and eating disorder more easily compared to the male.

This research is also in line with the opinion of Ikawati (2016), which stated that Compared to men, women who work more experience conflicting roles between careers and housewives, role conflict experienced by these women will tend to cause emotional distress that can lead to occurrence job stress. Furthermore, this research is also in line with the opinion of International Labour Organization (2018), which stated that female had a higher chance to experience job stress which may cause the occurrence of post-stress sickness and also a higher chance to retire from the job. Some factors make it easier for women to experience job stress, one of them is the higher familial and dominant responsibility, making the workload of the female was higher and tougher than the male counterpart.

This result was similar to the study conducted by Habibi and Jefri (2018) on the worker of PT. Borneo Melintang Buana Export production units, which shows that female respondents have 0.039 times higher risk of job stress compared to the male respondents.

\section{Marital Status and Job stress}

According to the analysis conducted by using the fisher's exact test, the P-value (1.000) is shown to have a bigger value compared to the value of $\alpha$ (0.05), which means that the connection between the marital status and job stress in the Quality Assurance and Quality Control Division did not exist. This result is the same as the study that was carried out by Nurini, et al. (2017) on the employees of PT. PLN (Persero) TJBT APP Cirebon which stated that the marital status was not significantly connected with the job stress.

The result of this study can also be seen in the study carried out by Aprianti and Surono (2018) on the permanent lecturer in Stikes Y Bengkulu, showing that there was not any significant connection between marital status and job stress. Marital status is one of many factors that may cause job stress, but in this study, the job stress was not affected by marital status because the workers were able to adapt, be it in the work environment or at home, meaning that familial problem was not brought at the workplace. Additionally, the family has permitted the employees to work. This result is also similar to that of a research performed by Wicaksono and Anggarini (2019) on workers in the business solution, support and service delivery division of PT Medika Jakarta Administration, which showed that the marital status had no connection with job stress.

From this study, workers who have not been married had a bigger chance to be affected by job stress. This means that single workers have a higher stress level compared to married workers. This result is similar to the opinion of Nurhidayati (2016), which stated that workers with marital status have lesser job stress levels compared to single workers. This happens because workers with marital status have the support of their family/couple, causing the 
less-likeliness of job stress to occur. This impact is categorized as positive if the marriage status is in harmony.

According to the opinion given by Ismail (2013), marital status could be a factor that triggers the occurrence of job stress in the workplace. However, not every married individual will experience job stress during their work. This is happened depending on the individual ability of the married couple itself to resolve and finish whatever problems that occur in their household. Setyani (2013) stated that for workers with marital status, a family condition might inflict, decrease, or prevent the job stress occurrence. This happened because workers with marriage problems will likely to experience job stress. But on the other side, if the marriage brings comfort, peace, and happiness, then problems that occur during the work will less likely to cause job stress.

\section{CONCLUSION}

To conclude, there is no significant relationship between individual characteristics including work period, age, gender, and marital status with job stress in the Quality Assurance and Quality Control Division of PT. PAL Indonesia (Persero).

\section{ACKNOWLEDGMENTS}

This study was fully funded by the author because this research is done independently. The highest form of praise and gratitude is given to the God Almighty, since it is only by the God's grace I am able to finish this research. A very special gratitude is given to PT. PAL Indonesia (Persero) for facilitating this research, and also to all of the workers from the Quality Assurance and Quality Control Division that is willing to be the respondents for this research. Gratitude is also given to my family and friends that have been the supreme source of supports and prayers so that I can finish this research.

\section{REFERENCES}

Anggraeni, A. D., Setyaningsih, Y. and Suroto (2017) 'Hubungan Antara Karakteristik Individu dan Intrinsik dengan Stres Kerja Pada Pekerja Sandblasting', Jurnal Kesehatan Masyarakat (e-Journal), 5(3), pp. 226-233.
Anoraga, P. (2014) Psikologi Kerja. Jakarta: PT. Rineka Cipta.

Ansori, R. R. and Martiana, T. (2017) 'Hubungan Faktor Karakteristik Individu Dan Kondisi Pekerjaan Terhadap Stres Kerja Pada Perawat Gigi', The Indonesian Journal of Public Health, 12(1), p. 75-84.

Aprianti, R. and Surono, A. (2018) 'Faktor-Faktor Yang Berhubungan Dengan Stres Kerja Pada Dosen Tetap di Stikes Y Bengkulu', Jurnal Photon, 9(1), pp. 189-196.

Bagus, Y. (2014) 'Perbedaan Jenis Kelamin dan Gender', Artikel Prezi, 5(1), pp. 1-5.

Febriandini, E. A., Ma'arufi, I. and Hartanti, R. I. (2016) 'Analisis Faktor Individu, Faktor Organisasi dan Kelelahan Kerja Terhadap Stres Kerja Pada Perawat (Studi di Ruang Rawat Inap Inpatient Unit 3rd Grade at General Hospitals Dr. H Koesnadi , Bondowoso District)', e-Jurnal Pustaka Kesehatan, 4(1), pp. 175-180.

Habibi, J. and Jefri (2018) 'Analisis Faktor Risiko Stres Kerja Pada Pekerja Di Unit Produksi Pt. Borneo Melintang Buana Export', Journal of Nursing and Public Health, 6(2), pp. 50-59.

Hartono and Siswanto (2017) 'Faktor - Faktor Yang Berhubungan Dengan Tingkat Stres Kerja Pada Perawat Bagian Rawat Inap Di Rumah Sakit Haji Jakarta Tahun 2017', Jurnal Kesehatan Masyarakat, 1(1), pp. 11-22.

Hermanto, B. (2012) Pengaruh Prestasi Training, Motivasi, dan Masa Kerja Teknisi Terhadap Produktivitas Teknisi Di Bengkel Nissan Yogyakarta, Solo dan Semarang. Undergraduate Thesis. Semarang; Faculty of Medicine Universitas Negeri Semarang.

Ikawati (2016) 'Sikap Keluarga terhadap Ibu atau Istri sebagai Wanita Karir', Jurnal PKS, 15(4), pp. 337-348.

International Labour Organization (2018) Improving the Safety and Health of Young Workers (Meningkatkan Keselamatan dan Kesehatan Pekerja Muda). Jakarta: ILO Publication, p.7

Ismail, C. S. (2013) Beberapa Faktor Yang Berhubungan Dengan Stres Kerja Pada Perawat Di Rumah Sakit Umum Bahteramas Provinsi Sulawesi Tenggara, Thesis. Makassar; Faculty of Public Health Universitas Hasanudin.

Koesindratmono, F. (2011) 'Hubungan antara Masa Kerja dengan Pemberdayaan Psikologis pada Karyawan PT. Perkebunan Nusantara X (Persero)', Insan Media Psikologi, 13(1), pp. $1-7$. 
Lady, L., Susihono, W. and Muslihati, A. (2017) 'Analisis Tingkat Stres Kerja dan Faktor-Faktor Penyebab Stres Kerja pada Pegawai BPBD Kota Cilegon', Journal Industrial Servicess, 3(1b), pp. 191-197.

Manabung, A. R., Suoth, L. F. and Warouw, F. (2018) 'Hubungan Antara Masa Kerja dan Beban Kerja dengan Stres Kerja pada Tenaga Kerja di PT. Pertamina TBBM Bitung', Jurnal Kesehatan Masyarakat, 7(5), pp. 1-10.

Mangkunegara (2013) Manajemen Sumber Daya Manusia Perusahaan. Bandung: PT. Remaja Rosda Karya.

Maydinar, D. D., Fernalia and Robiansyah, V. A. (2020) 'Hubungan Shift Kerja Dan Masa Kerja Dengan Stres Kerja Perawat Kamar Bedah RSUD Dr.M. Yunus Bengkulu Tahun 2019', CHMK Nursing Scientific Journal, 4(2), pp. 237-245.

Munandar, A. S. (2012) Psikologi Industri dan Organisasi. Jakarta: Universitas Indonesia (UIPress).

Nadialis, C. E. (2014) 'Hubungan Usia, Masa Kerja Dan Beban Kerja Dengan Stress Kerja Karyawan', Jurnal Ilmu Manajemen (JIM), 2(2). pp. 489-501.

Nurhidayati, W. (2016) Hubungan Suhu Ruangan dan Karakteristik Individu dengan Stres Kerja Pada Karyawan Di Unit Instalasi Binatu RSUP Dr. Sardjito Yogyakarta. Thesis. Yogyakarta: Faculty of Medicine and Health Sciences Universitas Gajah Mada.

Nurini, Rahmawati, A. and Nuraeni, T. (2017) 'Faktor yang Berhubungan dengan Stres Kerja Pada Karyawan di PT. PLN (Persero) TJBT APP Cirebon Factors that Concerned with Job Stress at employees at PT. PLN (Persero) TJBT APP Cirebon', Jurnal Kesehatan Masyarakat, 2(2), pp. 60-67.

Prabowo, Y. F. (2010) Stres Kerja Pada Bagian Produksi Industri Mebel PT. Chia Jiann Indonesia Furniture di Wedelan Jepara Tahun 2009. Universitas Negeri Semarang. Undergraduate Thesis. Semarang; Faculty of Sport Science Universitas Negeri Yogyakarta.

Rusmania, W. (2017) Perbedaan Pengaruh Terapi Musik Dengan Terapi Tertawa Terhadap Peningkatan Kualitas Tidur Pada Lanjut Usia. Undergraduate Thesis. Yogyakarta: Faculty of Health Sciences Universitas Aisyiyah Yogyakarta.

Setyani, T. W. (2013) Analisis Stress Kerja Dan Hubungannya Dengan Karakteristik Pekerja,
Kondisi Pekerjaan, dan Lingkungan Kerja pada Dosen di FKIK UIN Syarif Hidatyatullah. Undergraduate Thesis. Jakarta: Faculty of Medicine and Health Sciences Universitas Islam Negeri Syarif Hidayatullah.

Suma'mur. P.K (2014) Higiene Perusahaan dan Kesehatan Kerja. Jakarta: Sagung Seto.

Suci, I. S. M. . (2018) 'Analisis Hubungan Faktor Individu Dan Beban Kerja Mental Dengan Stres Kerja', The Indonesian Journal of Occupational Safety and Health, 7(2), p. 220-229.

Tarwaka (2015) Ergonomi Industri : Dasar Dasar Pengetahuan Ergonomi Dan Aplikasi Di Tempat Kerja. 2nd edn. Surakarta: Harapan Press.

The American Institute of Stress (2013) Workplace Stress. New York: Publishing American Institute of Stress.

The UK National Job stress s (2017) Job Stress s. 1st ed. United Kingdom: The Job stress s Network (UK National Job stress s Network).

Ulum, M. B., Wahyuni, I. and Ekawati (2018) 'Faktor-Faktor Yang Berhubungan Dengan Stres Kerja Pada Pengemudi Bus Rapid Transit (Brt) Koridor Ii Kota Semarang', Jurnal Kesehatan Masyarakat (e-Journal), 6(5), pp. 594-602.

Utami, G. B. (2010) Faktor-Faktor Yang Berhubungan dengan Kejadian Stres Kerja Pada Perawat Instalasi Rawat Inap B RS. PELNI Petamburan Jakarta Tahun 2009. Undergraduate Thesis. Jakarta; Faculty of Medicine and Health Sciences UIN Syarif Hidayatullah Jakarta.

Wicaksono, M. N. and Anggarini, I. M. (2019) 'Faktor-Faktor Yang Berhubungan Dengan Stres Kerja Pada Pekerja Divisi Business Solution, Support Dan Service Delivery PT Administrasi Medika Jakarta', Jurnal Ilmiah Kesehatan, 10(2), pp. 161-172.

Widyastuti, A. D. (2018) 'Hubungan Stres Kerja Dengan Kelelahan Kerja Pada Pekerja Area Workshop Konstruksi Box Truck', The Indonesian Journal of Occupational Safety and Health, 6(2), p. 216-224.

Wijono, S. (2010) Psikologi Industri dan Organisasi: Dalam Suatu Bidang Gerak Psikologi Sumber Daya Manusia. Jakarta: Prenadamedia Group.

Zulkifli, Shinta Tri R, S. A. A. (2019) 'Hubungan Usia , Masa Kerja dan Beban Kerja Dengan Stres Kerja Pada Karyawan Service Well Company PT . Elnusa TBK Wilayah Muara Badak, Jurnal Kesehatan Masyarakat, 5(1), pp. 47-61. 